Tropical Journal of Pharmaceutical Research January 2015; 14 (1): 141-147

ISSN: $1596-5996$ (print); 1596-9827 (electronic) (C) Pharmacotherapy Group, Faculty of Pharmacy, University of Benin, Benin City, 300001 Nigeria.

All rights reserved.

Available online at http://www.tjpr.org

Original Research Article

http://dx.doi.org/10.4314/tjpr.v14i1.20

\title{
Development and Validation of Reverse Phase High Performance Chromatography Method for Determination of Olanzapine in Microsample Rat Plasma: Application to Preclinical Pharmacokinetic Study
}

\author{
Fahad Pervaiz*, Mahmood Ahmad, Muhammad Usman Minhas and Muhammad \\ Sohail \\ Faculty of Pharmacy and Alternative Medicines, The Islamia University of Bahawalpur, 63100, Bahawalpur, Pakistan
}

*For correspondence: Email: fahad_bwp@yahoo.com; Tel: +92-3216805365; Fax: +92-62925556

Revised accepted: 21 December 2014

\begin{abstract}
Purpose: To develop a sensitive and validated reverse phase-high performance liquid chromatographic (RP-HPLC) method for quantification of olanzapine in micro-sample of rat plasma using UV detection. Methods: A single oral dose of olanzapine $(7 \mathrm{mg} / \mathrm{kg})$ was given to overnight fasted rats $(n=6)$. Rat plasma samples containing the drug were extracted by liquid-liquid extraction using a combination of dichloromethane: $n$-hexane (80:20). A reverse phase chromatographic column C18 hypersil-BDS was used for chromatographic separation with a mobile phase consisting of $50 \mathrm{mM}$ phosphate buffer $\mathrm{pH} 5.5$, acetonitrile and methanol (50:30:20, v/v/v) pumped at a flow rate of $1.2 \mathrm{~m} / \mathrm{min}$. Olanzapine was measured using ultraviolet (UV) detection at $214 \mathrm{~nm}$. The method was validated for precision and accuracy.

Results: Separation of compounds of interest was not affected by endogenous interference. Good linearity within the concentration range of $1-500 \mathrm{ng} / \mathrm{ml}$ in rat plasma was obtained with coefficient of regression $\left(r^{2}\right)$ of 0.9986. Liquid-liquid extraction produced comparable recovery to solid phase extraction. Retention time of olanzapine and internal standard (fluoxetine) was 5.0 and 13.4 min, respectively. Lowest limit of quantification (LLOQ) was $1 \mathrm{ng} / \mathrm{ml}$ while inter-day and intra-day precision was $<12.5$ and $5.1 \%$, respectively. Accuracy of the method was between 94 and $105 \%$ and the variation of results between two analysts was not significant $(p=0.626)$. Mean maximum plasma concentration (Cmax) of olanzapine was $412.7 \mathrm{ng} / \mathrm{ml}$, time to attain maximum plasma concentration (tmax) was $1 \mathrm{~h}$ and half life $\left(t_{1 / 2}\right)$ was $2.54 \mathrm{~h}$.

Conclusion: The proposed method has been successfully validated for precision and accuracy that are within the limits of U.S. Food and Drug Administration (FDA)'s guidance for bioanalyitcal assay validation. The method was successfully applied to preclinical pharmacokinetic analysis of olanzapine in rats.
\end{abstract}

Keywords: Olanzapine, Antipsychotic, Pharmacokinetics, Rat, Plasma, Bioanalytical assay

Tropical Journal of Pharmaceutical Research is indexed by Science Citation Index (SciSearch), Scopus, International Pharmaceutical Abstract, Chemical Abstracts, Embase, Index Copernicus, EBSCO, African Index Medicus, JournalSeek, Journal Citation Reports/Science Edition, Directory of Open Access Journals (DOAJ), African Journal Online, Bioline International, Open-J-Gate and Pharmacy Abstracts

\section{INTRODUCTION}

Olanzapine is a thienobenzodiazipine derivative which is an atypical antipsychotic effectively used in the treatment of schizophrenia and bipolar disorders [1,2]. Olanzapine has shown to have affinity with dopamine D1 and D2, muscarinic and serotonin 5HT2 receptors [3]. Plasma 
concentration of olanzapine has a correlation with its clinical effects and also shown to have individual variability in its pharmacokinetics $[4,5]$. Many drug interactions with olanzapine have also shown to change the pharmacokinetics of olanzapine [6].<smiles>Cc1cc2c(s1)Nc1ccccc1N=C2N1CCN(C)CC1</smiles>

Figure 1: Chemical structure of olanzapine

Analysis of olanzapine from biological samples is widely carried out by high performance liquid chromatography (HPLC). Previous studies have reported several HPLC methods employing electrochemical, amperometric, ultraviolet and mass spectroscopic detection [7-11]. The HPLC method employed in the present study utilizes ultraviolet detection for analysis and is convenient, affordable, easily available and requires less maintenance than other detection methods. The method was applied to microsample rat plasma because minimal amount of blood can be withdrawn for a small animal like rat for repeated blood sampling. Current method was aimed to provide desired recovery and sensitivity of assay by employing liquid-liquid extraction procedure.

\section{EXPERIMENTAL}

\section{Materials}

Pure drug samples of olanzapine (2-methyl-4-(4methyl-1-piperazinyl)-10H

thieno[2,3][1,5]benzodiazepine) and flouxetine were kindly provided by Miracle Pharmaceuticals (Islamabad, Pakistan). HPLC-grade acetonitrile, methanol and ethanol were obtained from Merck (Germany) and used without further purification or filtration. All other chemicals used were of analytical grade or higher.

\section{Chromatographic instrumentation conditions}

and

Chromatographic studies were performed on Agilent separation module combined with solvent delivery pump model 1100 (USA). Chromatographic data was obtained by using computerized integration software HP ChemStation. A reverse phase chromatographic column C18 hypersil-BDS (250 - 4.6 mm; i.d., 5 $\mu \mathrm{m})$ was used. The mobile phase consisted of 50 $\%$ phosphate buffer of $50 \mathrm{mM}$ maintained at $\mathrm{pH}$ 5.5- Acetonitrile-methanol (50:30:20) (v/v/v) which was run at the flow rate of $1.2 \mathrm{ml} / \mathrm{min}$. Mobile phase was filtered through $0.45 \mu \mathrm{m}$ membrane by vacuum filtration and degassed by ultrasonicator prior to use. Detection of olanzapine was carried out on an ultraviolet detector at $214 \mathrm{~nm}$.

\section{Sample preparation}

Quantification of olanzapine in micro-sample rat plasma was carried out using a modified HPLC method according to previously published HPLC method by Dusci et al [12]. Olanzapine was extracted from the rat plasma samples by using liquid-liquid extraction. $0.1 \mathrm{ml}$ of plasma was taken in a $10 \mathrm{ml}$ borosilicate glass tube, $10 \mu \mathrm{l}$ of internal standard (I.S.) solution (5 $\mu \mathrm{g} / \mathrm{ml}$ of fluoxetine) was added to biological sample. 300 $\mu \mathrm{l}$ of $0.1 \mathrm{M} \mathrm{Na}_{2} \mathrm{CO}_{3}$ and $5 \mathrm{ml}$ solution of hexane: dichloromethane (80:20) was added. The mixture was shaken for $5 \mathrm{~min}$ on a vortex mixer then centrifuged at $2000 \mathrm{~g}$ for $5 \mathrm{~min}$. Supernatant from this mixture was transferred to a $10 \mathrm{ml}$ glass tube and evaporated under the stream of nitrogen. $100 \mu \mathrm{l}$ of mobile phase was added and mixed on a vortex mixer. Fifty microliters of this sample was injected to HPLC for analysis.

\section{Preparation of stock solutions}

Stock solutions of olanzapine and fluoxetine were prepared at concentration of $1 \mathrm{mg} / \mathrm{ml}$ in methanol. For preparation of working standard solutions these stock solutions were further diluted with methanol. For olanzapine, its standard working solutions were $0.01,0.05,0.1$, $0.5,1.0,2.0,5.0 \mu \mathrm{g} / \mathrm{ml}$. For fluoxetine, its standard working solution was $5.0 \mu \mathrm{g} / \mathrm{ml}$.

\section{Method validation}

\section{Linearity}

Standard calibration curves were prepared by adding $10 \mu \mathrm{l}$ of standard working dilutions of olanzapine and fluoxetine to $0.1 \mathrm{ml}$ drug free rat plasma. Thus, corresponding plasma calibration standards of concentration 1, 5, 10, 50, 100, 200, $500 \mathrm{ng} / \mathrm{ml}$ were obtained. Plasma calibration standards were extracted by liquid-liquid extraction as method described above. Standard calibration curves were calculated by using peak area ratio of olanzapine and that of fluoxetine as function of olanzapine concentration in plasma. 


\section{Recovery}

Absolute recovery was calculated by comparing the peak areas of compounds after liquid-liquid extraction with same concentration of compounds dissolved in mobile phase. To determine absolute recovery, each measurement was carried out in triplicate and computed as in Eq 1.

Recovery $(\%)=(\mathrm{Pe} / \mathrm{Pu}) 100$

where $\mathrm{Pe}$ and $\mathrm{Pu}$ are the peak area of extracted and unextracted standards, respectively.

\section{Assessment of intra-day and inter-day variability}

Five different rat plasma samples were tested for intra-day variability by using a single calibration curve. Inter-day variability was tested on five days by using five different rat plasma samples. Standard calibration curve was constructed on each day for analysis.

\section{Determination of $L L O Q$ and $L O D$}

Lower limit of quantification (LLOQ) and lower limit of detection (LOD) for plasma samples of olanzapine was determined according to standards of FDA's guidance for industry for bioanalytical method validation 2013 [13]. LLOQ was determined by spiking the plasma with lowest concentration of calibration curve with 20 $\%$ of precision and with $80-120 \%$ of accuracy by repeated analysis for five days.

\section{Stability}

Freeze and thaw stability was determined by comparing freshly prepared QC samples with freeze thawed samples. Three concentrations (5, $100,500 \mathrm{ng} / \mathrm{ml}$ ) were used for five cycles of freeze thaw and analyzed in triplicates. Benchtop stability for $24 \mathrm{~h}$ at room temperature, stability for extracted sample for $24 \mathrm{~h}$ at room temperature and long term stability for 100 days at $-30{ }^{\circ} \mathrm{C}$ was measured in three concentrations $(5,100,500 \mathrm{ng} / \mathrm{ml})$ with six replicates.

\section{Application to pharmacokinetic studies}

Above method was applied for pharmacokinetic evaluation of olanzapine in rats for preclinical studies. The animal study was approved by Pharmacy Research Ethics Committee, Department of Pharmacy, the Islamia University of Bahawalpur (Ref. no. 101-2011/PREC). All experiments were performed in accordance with international guidelines for animal studies [14]. Sprague-Dawley rats $(260 \pm 30 \mathrm{~g})$ were housed with free access to food and water. An oral single dose of olanzapine $(7 \mathrm{mg} / \mathrm{kg})$ was given to overnight fasted rats $(n=6)$ and blood samples $(0.5 \mathrm{ml})$ were collected from each rat at $0.5,1,3$, $6,12,24 \mathrm{~h}$ via the tail vein. The blood samples were centrifuged to separate the plasma which was then stored in the dark at $-30{ }^{\circ} \mathrm{C}$. Pharmacokinetic parameters i.e. time to attain maximum plasma concentration $\left(T_{\text {max }}\right)$, maximum plasma concentration $\left(\mathrm{C}_{\max }\right)$, area under the plasma concentration-time curve from zero hour to last time point $\left(A \cup C_{\text {last }}\right)$, area under the plasma concentration-time curve from zero hour to infinity $\left(A \cup C_{\infty}\right)$ and mean residence time (MRT) were calculated using a software Thermo Kinetica 5.0 (Thermo Fisher Scientific, USA).

\section{Statistical analysis}

The results are presented as mean \pm S.D, percent relative standard deviation (\% RSD) and coefficient of variation (CV). The results were analyzed for significant difference using Student's t-test and differences were considered significant at $p \leq 0.05$. All statistical analyses were performed using Microsoft Excel 2010 software.

\section{RESULTS}

\section{Chromatographic separation}

Different ratios of buffer, acetonitrile and methanol were used to obtain the best chromatographic conditions. Type of column and $\mathrm{pH}$ of buffer was also optimized to get the better sensitivity and selectivity of analysis. Chromatograms of blank plasma and drug free plasma spiked with $100 \mathrm{ng}$ of olanzapine and $500 \mathrm{ng}$ of fluoxetine (I.S) is illustrated in (Figure 2 ). Retention times of olanzapine and internal standard (fluoxetine) were 5.0 and $13.4 \mathrm{~min}$, respectively.

\section{Linearity and limit of quantification}

Standard curve was established by taking ratio of peak area of olanzapine and that of fluoxetine (I.S) as a function of olanzapine plasma concentration. Excellent linearity with concentration range $1-500 \mathrm{ng} / \mathrm{ml}$ in rat plasma was obtained with coefficient of regression i.e., $r^{2}$ $=0.9986$. Lowest limit of quantification (LLOQ) in rat plasma with acceptable precision and accuracy ( $n=5$, R.S.D.: $12.4 \%$, Deviation: $-3 \%$ ) 

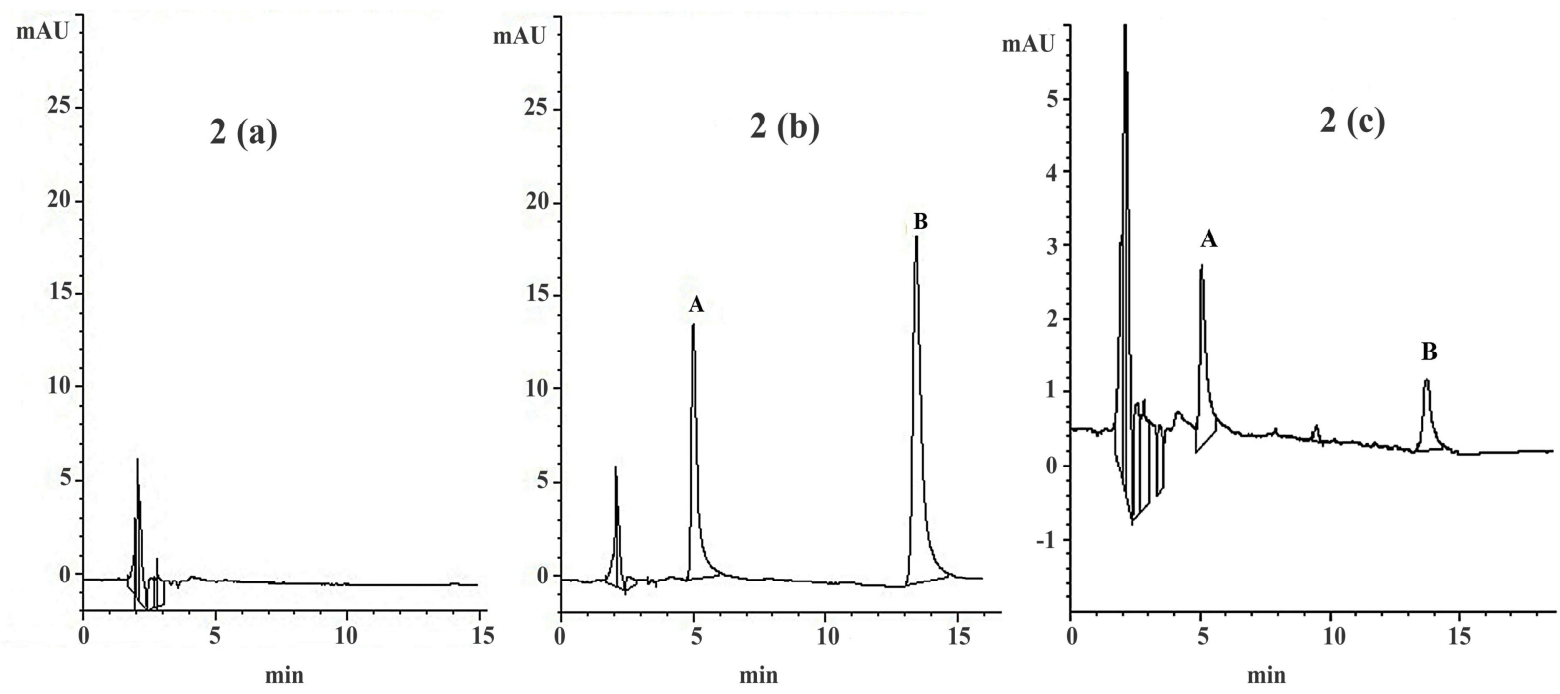

Figure 2: Chromatogram of rat plasma extract using UV detection at $214 \mathrm{~nm} .2(\mathrm{a})=$ blank plasma; 2(b) = plasma spiked with olanzapine $100 \mathrm{ng} / \mathrm{ml}(\mathrm{A})$ and fluoxetine $500 \mathrm{ng} / \mathrm{ml}(\mathrm{B}) ; 2(\mathrm{c})$ = plasma sample taken from rat treated with $7 \mathrm{mg} / \mathrm{kg}$ after $24 \mathrm{~h}$ and spiked with internal standard fluoxetine $50 \mathrm{ng} / \mathrm{ml}$

was $1 \mathrm{ng} / \mathrm{ml}$. Limit of detection was $0.5 \mathrm{ng} / \mathrm{ml}$ with minimum signal to noise ratio of three.

\section{Precision and accuracy}

Inter-day and intra-day accuracy and precision values for $1,5,10,50,100,200,500 \mathrm{ng} / \mathrm{ml}$ plasma concentration are shown in (Table 1). Five replicates were used to determine the Interday and intra-day precision by calculating RSD $\%$. Inter-day and intra-day precision was found to be lower than 12.5 and $5.1 \%$, respectively, whereas accuracy of this method was between $94 \%$ and $105 \%$. Variation between two analysts was also determined by applying t-test. The mean drug content determined by analysts 1 and
2 was $99.43 \pm 0.12$ and $99.37 \pm 0.30$, respectively. There was no significant difference between these two results $(p=0.626)$.

\section{Extraction recovery}

A convenient single step liquid-liquid extraction method was employed which provided a comparable recovery to other methods employing solid phase extraction (SPE). Extraction recovery of olanzapine was measured at $1,50,500 \mathrm{ng} / \mathrm{ml}$ and $500 \mathrm{ng} / \mathrm{ml}$ for fluoxetine (I.S) using triplicate samples. Extraction recoveries of olanzapine and internal standard are shown in (Table 2).

Table 1: Inter-day and intra-day precision and accuracy of HPLC method for olanzapine in rat plasma

\begin{tabular}{lcccc}
\hline $\begin{array}{l}\text { Concentration spiked } \\
\text { (ng/ml) }\end{array}$ & $\begin{array}{c}\text { Mean concentration } \\
\text { (calculated, } \mathbf{n g} / \mathbf{m l})\end{array}$ & SD & RSD (\%) & Accuracy (\%) \\
\hline Inter-day $(\boldsymbol{n}=5)$ & 1.05 & 0.13 & 12.4 & 105 \\
1 & 4.92 & 0.08 & 1.7 & 98.4 \\
5 & 47 & 3.46 & 7.4 & 94 \\
50 & 97.70 & 4.68 & 4.8 & 97.7 \\
100 & 201.1 & 0.85 & 0.4 & 100.6 \\
200 & 484.4 & 28.94 & 6.0 & 96.9 \\
500 & & & & \\
Intra-day (n=5) & 0.96 & 0.02 & 1.6 & 95.7 \\
1 & 5.04 & 0.25 & 5.0 & 100.8 \\
5 & 47.97 & 0.71 & 1.5 & 95.9 \\
50 & 100.87 & 2.46 & 2.4 & 100.9 \\
100 & 197.23 & 2.95 & 1.5 & 98.6 \\
200 & 485.67 & 5.03 & 1.0 & 97.1 \\
500 & & & & \\
\hline
\end{tabular}

${ }^{a} R S D$ values of normalized areas are the mean of three concentration levels of the calibration curves; $S D=$ standard deviation 
Table 2: Percentage extraction recoveries of olanzapine and fluoxetine from rat plasma

\begin{tabular}{|c|c|c|c|}
\hline \multirow[t]{2}{*}{$\begin{array}{l}\text { Concentration } \\
\text { spiked (ng/ml) }\end{array}$} & \multicolumn{2}{|c|}{$\begin{array}{c}\text { Peak area } \\
(m e a n \pm S D, n=3)\end{array}$} & \multirow[t]{2}{*}{$\begin{array}{c}\text { Recovery } \\
(\%)^{b}\end{array}$} \\
\hline & Extracted & Unextracted & \\
\hline \multicolumn{4}{|l|}{ Olanzapine } \\
\hline 1 & $2.4 \pm 0.1$ & $2.8 \pm 0.1$ & 83 \\
\hline 50 & $114.0 \pm 1.4$ & $133.2 \pm 1.3$ & 86 \\
\hline 500 & $1177.4 \pm 31.0$ & $1275.2 \pm 11.0$ & 92 \\
\hline \multicolumn{4}{|c|}{ Fluoxetine (I.S) } \\
\hline 500 & $446.2 \pm 2.9$ & $508.2 \pm 3.0$ & 88 \\
\hline
\end{tabular}

b Recovery; mean values obtained from three individual samples on three different days at three concentration levels

\section{Stability}

Changes in stability for plasma samples stored at $-30{ }^{\circ} \mathrm{C}$ after 5 freeze thawing cycles is shown in (Table 3). Bench-top stability and extracted sample stability were measured at room temperature and long term stability was measured at $-30{ }^{\circ} \mathrm{C}$ as shown in (Table 4).

Long term stability for olanzapine in plasma sample at $-30{ }^{\circ} \mathrm{C}$ was for a minimum of 100 days.
Application of validated method to pharmacokinetic studies

Plasma concentration versus time curves after 7 $\mathrm{mg} / \mathrm{kg}$ oral administration of olanzapine is shown in Figure 3.

Non-compartmental pharmacokinetic parameter were calculated by Kinetica 5.0 software (Thermo Fisher Scientific, USA), which are described in (Table 5). The mean $\mathrm{C}_{\max }$ of olanzapine was $412.7 \mathrm{ng} / \mathrm{ml}, \mathrm{t}_{\max }$ was $1 \mathrm{~h}$ and half life $\left(\mathrm{t}_{1 / 2}\right)$ was $2.54 \mathrm{~h}$.

\section{DISCUSSION}

Using the current method the chromatographic separation for micro-sample rat plasma was made with reasonable retention times. Method validation was performed, and precision and accuracy of the developed method for determining olanzapine in plasma is within the limits established by FDA for bioanalytical method [13].

Table 3: Freeze thaw stability of plasma samples after 5 cycles $(n=3)$

\begin{tabular}{|c|c|c|c|c|}
\hline Cycle & $\begin{array}{c}\text { Concentration } \\
(\mathrm{ng} / \mathrm{ml})\end{array}$ & $\begin{array}{c}\text { Mean stability sample } \\
(\mathrm{ng} / \mathrm{ml})\end{array}$ & $\begin{array}{l}\mathrm{CV} \\
(\%)^{a}\end{array}$ & Change $(\%)^{D}$ \\
\hline \multirow[t]{3}{*}{1} & 5 & 4.93 & 2.1 & -1.4 \\
\hline & 100 & 98.4 & 3.5 & -1.6 \\
\hline & 500 & 495.1 & 2.8 & -0.98 \\
\hline \multirow[t]{3}{*}{2} & 5 & 4.91 & 6.1 & -1.8 \\
\hline & 100 & 98.5 & 5.4 & -1.5 \\
\hline & 500 & 492.3 & 3.8 & -1.54 \\
\hline \multirow[t]{3}{*}{3} & 5 & 4.88 & 1.9 & -2.4 \\
\hline & 100 & 91.9 & 6.5 & -8.1 \\
\hline & 500 & 491.2 & 3.9 & -1.76 \\
\hline \multirow[t]{3}{*}{4} & 5 & 4.81 & 2.4 & -3.8 \\
\hline & 100 & 90.7 & 1.5 & -9.3 \\
\hline & 500 & 486.4 & 4.1 & -2.72 \\
\hline \multirow[t]{3}{*}{5} & 5 & 4.7 & 1.9 & -6 \\
\hline & 100 & 90.3 & 3.4 & -9.7 \\
\hline & 500 & 485.1 & 2.9 & -2.98 \\
\hline
\end{tabular}

Table 4: Stability parameters of olanzapine plasma samples at different storage conditions $(n=6)$

\begin{tabular}{lccccc}
\hline Stability variable & Storage condition & $\begin{array}{c}\text { Concentration } \\
\text { (ng/ml) }\end{array}$ & $\begin{array}{c}\text { Mean stability sample } \\
(\mathbf{n g} / \mathbf{m l})\end{array}$ & $\begin{array}{c}\text { CV } \\
(\mathbf{\%})^{\mathbf{a}}\end{array}$ & $\begin{array}{c}\text { Change } \\
(\mathbf{\%})^{b}\end{array}$ \\
\hline Bench top stability & Room temperature & 5 & 4.87 & 1.3 & -2.6 \\
& for $24 \mathrm{~h}$ & 100 & 98 & 3.2 & -2 \\
& & 500 & 493.5 & 0.9 & -1.3 \\
Long term stability & $\mathrm{At}-30{ }^{\circ} \mathrm{C}$ for 100 & 5 & 4.81 & 5.3 & -3.8 \\
& days & 100 & 90.7 & 2.8 & -9.3 \\
& & 500 & 485.6 & 3.7 & -2.88 \\
Extracted sample & Room temperature & 5 & 4.95 & 0.5 & -1.0 \\
stability & for 48 h & 100 & 98.8 & 1.8 & -1.2 \\
& & 500 & 498.9 & 2.8 & -0.22 \\
\hline
\end{tabular}

${ }^{a} \mathrm{CV}=$ coefficient of variation; ${ }^{b}$ percent change in concentration at the end of the stability study 


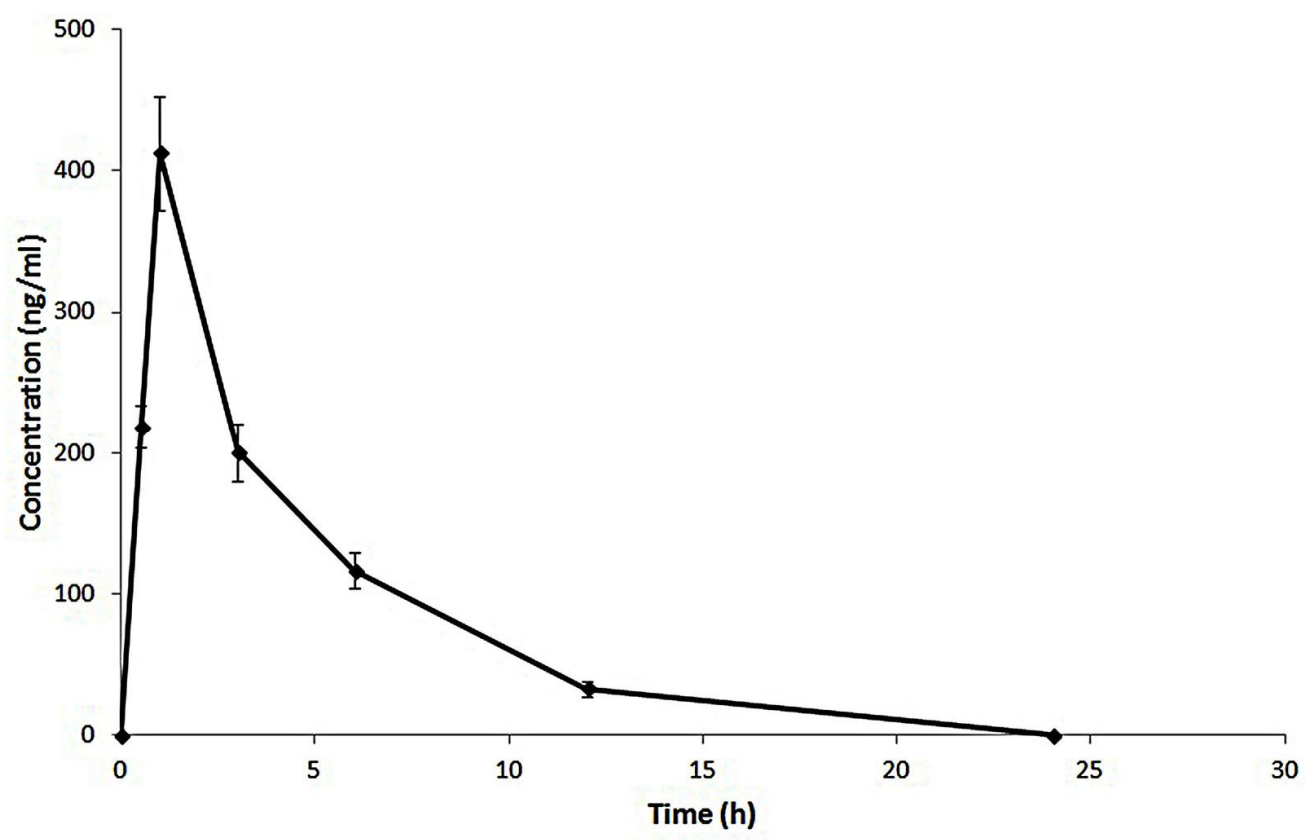

Figure 3: Mean plasma concentration-time plot after oral administration of $7 \mathrm{mg} / \mathrm{kg}$ of olanzapine in rats

Table 5: Non-compartmental pharmacokinetic parameters (mean $\pm S D, n=6$ ) of olanzapine in rats after an oral dose of $7 \mathrm{mg} / \mathrm{kg}$

\begin{tabular}{|c|c|c|c|c|c|c|}
\hline Drug & $\begin{array}{l}T_{\max } \\
\text { (h) }\end{array}$ & $\begin{array}{c}\mathrm{C}_{\max } \\
(\mathrm{ng} / \mathrm{ml})\end{array}$ & $\begin{array}{l}\text { Half life }\left(t_{1 / 2}\right) \\
\text { (h) }\end{array}$ & $\begin{array}{c}\text { AUC }_{\text {last }} \\
\text { (ng.h/ml) }\end{array}$ & $\begin{array}{c}\text { AUC }_{\infty} \\
\text { (ng.h/ml) }\end{array}$ & $\begin{array}{c}\text { MRT } \\
\text { (h) }\end{array}$ \\
\hline Olanzapine & 1 & $412.7 \pm 18.7$ & 2.54 & $1956.7 \pm 119.2$ & $1959.5 \pm 119.5$ & 4.6 \\
\hline
\end{tabular}

$T_{\max }=$ time point for maximum plasma concentration, $C_{\text {max }}$ : maximum plasma concentration, $A U C$ last $=$ area under the plasma concentration-time curve from zero hour to last time point, $A \cup C_{\infty}=$ area under the plasma concentration-time curve from zero hour to infinity, $M R T=$ mean residence time

Results showed that extraction recovery was > $82 \%$ for all observed concentration in rat plasma which is comparable with SPE method [8,14]. Ascorbic acid was not added to the plasma samples as addition of ascorbic acid does not affect the stability of olanzapine during storage and extraction [12]. All the stability parameters were found to meet the acceptance criteria of FDA's Guidance for Industry for Bioanalytical Method Validation 2013 [13]. The mean $C_{\max }$ of olanzapine was $412.7 \mathrm{ng} / \mathrm{ml}, \mathrm{t}_{\max } 1 \mathrm{~h}$ and $\mathrm{t}_{1 / 2} 2.54$ $\mathrm{h}$ and are in accordance with the pharmacokinetic parameters observed in previous studies $[8,15]$.

\section{CONCLUSION}

A validated, precise and accurate isocratic RPHPLC method for determining olanzapine in micro-sample rat plasma has been developed in this study. Single-step liquid-liquid extraction provides sufficient recovery to quantify 1 - 500 $\mathrm{ng} / \mathrm{ml}$ of olanzapine in rat plasma. The method has been successfully applied to preclinical pharmacokinetic studies of olanzapine in rats.

\section{REFERENCES}

1. Scherk H, Pajonk FG, Leucht S. Second-generation antipsychotic agents in the treatment of acute mania: a systematic review and meta-analysis of randomized controlled trials. Arch Gen Psychiatry 2007; 64: 442455.

2. Moore N, Calligaro D, Wong D, Bymaster F, Tye N. The pharmacology of olanzapine and other new antipsychotic agents. Curr Opin Invest Drugs 1993; 2: 281-293.

3. Van Der Zwaal EM, Luijendijk M, Adan RA, La Fleur S.E. Olanzapine-induced weight gain: chronic infusion using osmotic minipumps does not result in stable plasma levels due to degradation of olanzapine in solution. Eur J Pharmacol 2008; 585: 130-136.

4. Preskorn SH, Burke MJ, Fast GA. Therapeutic drug monitoring: Principles and practice. Psychiatr Clin North Am 1993; 16: 611-645.

5. Perry PJ, Sanger T, Beasley C. Olanzapine plasma concentrations and clinical response in acutely ill schizophrenic patients. J Clin Psychol 1997; 17: 472477.

6. Olesen OV, Linnet $K$. Olanzapine serum concentrations in psychiatric patients given standard doses: the 
influence of comedication. Ther Drug Monit 1999; 21 : 87-90.

7. Aravagiri M, Ames D, Wirshing WC, Marder SR. Plasma level monitoring of olanzapine in patients with schizophrenia: determination by high-performance liquid chromatography with electrochemical detection. Ther Drug Monit 1997; 19: 307-313.

8. Chiu JA, Franklin RB. Analysis and pharmacokinetics of olanzapine (LY170053) and two metabolites in rat plasma using reversed-phase HPLC with electrochemical detection. J Pharm Biomed Anal 1996; 14: 609-615.

9. Catlow JT, Barton RD, Clements M, Gillespie TA, Goodwin M, Swanson SP. Analysis of olanzapine in human plasma utilizing reversed-phase highperformance liquid chromatography with electrochemical detection. J Chromatogr B Biomed Sci Appl 1995; 668: 85-90.

10. Bogusz M, Krüger K, Maier R, Erkwoh R, Tuchtenhagen F. Monitoring of olanzapine in serum by liquid chromatography-atmospheric pressure chemical ionization mass spectrometry. J Chromatogr $B$ Biomed Sci Appl 1999; 732: 257-269.

11. Olesen OV, Linnet $K$. Determination of olanzapine in serum by high-performance liquid chromatography using ultraviolet detection considering the easy oxidability of the compound and the presence of other psychotropic drugs. J Chromatogr B Biomed Sci Appl 1998; 714: 309-315.

12. Dusci LJ, Peter Hackett L, Fellows LM, llett KF. Determination of olanzapine in plasma by highperformance liquid chromatography using ultraviolet absorbance detection. Journal of Chromatography $B$ 2002; 773: 191-197.

13. Guidance for industry: Bioanalytical Method Validation. US Department of Health and Human Services [cited 2014 Jan 11]. Available from: http://www.fda.gov/downloads/Drugs/GuidanceCompl ianceRegulatoryInformation/Guidances/UCM368107. pdf

14. National Institutes of Health. Guide for the care and use of laboratory animals. Washington: National Academies; 2011[cited 2014 Jan 15]. Available from: http://grants.nih.gov/grants/olaw/Guide-for-the-careand-use-of-laboratory-animals.pdf

15. Raggi M, Casamenti G, Mandrioli R, Fanali S, De Ronchi $D$, Volterra $V$. Determination of the novel antipsychotic drug olanzapine in human plasma using HPLC with amperometric detection. Chromatographia 2000; 51: 562-566. 